\title{
PEMERIKSAAN ASAM URAT DAN KOLESTEROL DI LAPAS PANGKALAN BUN ${ }^{1}$ Risa Wahyuningsih \\ ${ }^{1}$ Stikes Borneo Cendekia Medika Pangkalan Bun \\ ${ }^{1}$ Email: risa.analisbcm16@yahoo.co.id
}

\begin{abstract}
Abstrak
Adanya penyakit Asam urat dan kolesterol banyak diderita oleh masyarakat. Kegiatan pengabdian masyarakat ini bertujuan untuk memberikan penyuluhan dan melakukan pemeriksaan kadar asam urat dan kolesterol. Hasil penelitian diketahui pria peminum kopi ringan peningkatan asam urat sebanyak 11 orang sedangan peminum kopi ringan peningkatan asam urat sebanyak 9 orang. Pria peminum kopi ringan peningkatan kolesterol sebanyak 29 sedangkan peminum kopi ringan peningkatan asam urat sebanyak 14 orang.
\end{abstract}

Kata Kunci: kopi, asam urat, kolesterol

\section{Abstract}

The existence of gout and cholesterol disease suffered by many people. This community service activity aims to provide counseling and check uric acid and cholesterol levels. The results of the study found that men who drink mild coffee increased uric acid by 11 people while light coffee drinkers increased by uric acid by 9 people. Male light coffee drinkers increased cholesterol by 29 while mild coffee drinkers increased uric acid by 14 people.

Keywords: coffee, gout, cholesterol

PENDAHULUAN

Perguruan tinggi telah diketahui memiliki tiga tugas utama kegiatan akademik, yaitu menyelenggarakan pendidikan, penelitian dan pengabdian kepada masyarakat yang selama ini dikenal sebagai Tridarma perguruan tinggi. Pada umumnya perguruan tinggi memiliki dasar pemikiran yang dilandasi oleh keinginan agar perguruan tinggi tidak hanya sebagai pemberi pedoman ilmu tetapi juga berpikir secara konseptual yang memiliki kepekaan sosial atau kepedulian lingkungan ditengah-tengah masyarakat.
Pengabdian kepada masyarakat mempunyai landasan terhadap konsep bahwa disamping memiliki kemampuan intelektual/akademik sekaligus sebagai makhluk sosial yang memperhatikan lingkungan kehidupan masyarakan dan juga peduli terhadap sesama makhluk hidup.

Pengabdian ke masyarakat merupakan kegiatan yang dilakukan baik individu, kelompok atau bersama-sama untuk membantu masyarakat sesuai dengan visi dan misi yang diembannya, baik berupa pengalaman ilmu 
pengetahuan, teknologi, seni maupun kesehatan yang langsung dilaksanakan ke masyarakat secara institusional dan profesional sebagai salah satu tugas tanggung jawab terhadap perguruan tinggi. Kegiatan pengabdian masyarakan yang dilakukan STIKes Borneo Cendekia Medika Pangkalan Bun yaitu dalam rangka kegiatan berbuka puasa selain itu juga ada kegiatan pemeriksaan gratis penyakit asam urat dan kolesterol.

Asam urat merupakan salah satu dari beberapa penyakit yang sangat membahayakan, karena bukan hanya menganggu kesehatan tetapi juga dapat mengakibatkan cacat fisik (Asaidi., 2010). Penyakit asam urat berhubungan dengan pola asupan makanan sehingga salah satu cara pencegahan dengan menjaga asupan makanan yang dapat menyebabkan kadar asam urat meningkat.

Angka kejadian penyakit artritis gout cenderung memaski usia semakin muda, yaitu usia produktif dimana diketahui prevalensi asam urat di Indonesia yang terjadi pada usia di bawah 34 tahun yaitu sebesar $32 \%$ dengan kejadian tertinggi pada penduduk Minahasa sebesar 29,2\% (Kumalasari et al., 2009). Faktor risikio kadar asam urat meningkat yaitu umur, genetik, asupan purin yang berlebihan, obesitas, penyakit jantung dan konsumsi obat-obatan tertentu dan gangguan fungsi ginjal (Sustrani et al., 2004). Menurut
Budiono et al., 2016, bahwa prevalensi obesitas dan status gizi dapat mempengaruhi kadar asam urat dalam darah.

Tingginya kadar kolesterol didalam darah merupakan permasalahan yang serius karena merupakan salah satu faktor resiko dari berbagai macam penyakit tidak menular seperti jantung, stroke, dan diabetes melitus. Kadar kolesterol yang berlebih dalam darah akan memudahkan melekat pada dinding sebelah dalam pembuluh darah.

Prevalensi hiperkolesterolemia di Indonesia menurut Survei Kesehatan Rumah Tangga (SKRT) tahun 2004 pada kelompok usia 25-34 tahun adalah 9,3\% dan meningkat seiring betam-bahnya usia pada kelompok usia 53-64 tahun sebe-sar $15,5 \%$ Untuk prevalensi hiperkolesterolemia di Indonesia sebesar 1,5\% pada laki-laki dan 2,2 pada perempuan Hasil Riskesdas tahun 2013 pro-porsi penduduk Indonesia dengan kadar kolesterol di atas normal lebih tinggi pada perempuan yaitu sebesar 39,6\% jika dibandingkan dengan laki-laki sebesar $30 \%$.

(Kemenkes RI., 2004). Berdasarkan latar belakang yang telah dijelaskan bahwa tujuan ini bertujuan untuk mengetahui jumlah penderita penyakit asam urat dan kolesterol pada peminum kopi ringan dan berat di Lapas Pangkalan Bun. 


\section{Metodelogi}

Alat

Alat yang digunakan pada kegiatan ini meliputi: Easy Touch GCU, Strip asam urat, Strip kolesterol

\section{Bahan}

Bahan yang digunakan pada kegiatan ini meliputi: Alkohol 70\%, Kapas, Tisu, Lancip steril., Handscoon dan Masker

\section{Cara Kerja}

1. Siapkan alat dan bahan yang digunakan untuk melakukan pemeriksaan asam urat.

2. Bersihkan ujung jari dengan menggunakan alkohol 70\%, diamkan sampai kering.

3. Tusuk ujung jari yang sudah dibersihkan dengan menggunakan lancip steril.

4. Bagian darah pertama dibuang kemudian darah yang berikutnya disentuh pada tepi sampring strip dan bukan ditetes diatas tengah strip alat test darah Easy Touch.

5. Darah akan lansung meresap sampai ujung strip.

6. Tunggu sebentar, hasil akan keluar beberapa detik pada layar.

7. Ditulis hasil pemeriksaan asam urat dan kolesterol.

8. Setelah selesai melakukan pemeriksaan cabut jarumnya dari lancing dan dibuang.

9. Chip di buang ke Disposafe box
10. Tutup rapat botol strip apabila tidak dipakai.

\section{HASIL DAN PEMBAHASAN}

A. Kategori Pemeriksaan Kadar Asam Urat Pria peminum kopi

Tabel 1. Distribusi frekuensi kategori kadar asam urat

\begin{tabular}{llll}
\hline Kategori & \multicolumn{2}{l}{ Kadar asam urat } \\
\cline { 2 - 3 } pemeriksaan & Normal & Tinggi & Total \\
\hline Ringan & 23 & 11 & 34 \\
Berat & 27 & 9 & 36 \\
\hline Total & 50 & 20 & 70 \\
\hline
\end{tabular}

Didapatkan sampel responden 70 orang usia 45-65 tahun peminum kopi pada kategori asam urat peminum kopi ringan kadar asam urat normal sebanyak 23 orang dan kadar asam urat tinggi sebanyak 11 orang sedangkan peminum kopi berat kadar asam urat normal sebanyak 27 orang dan kadar asam urat tinggi sebanyak 9 orang. Diketahui jumlah minum kopi ringan pada pria sebanyak 34 orang.

Kadar asam urat tinggi minum kopi ringan sebanyak 11 orang. Biasanya mulai terdapat kenaikan kadar asam urat yang terjadi karena penurunan fungsi ginjal dalam proses ekskresi sisa metabolisme dalam tubuh yang ditandai dengan kadar ureum dengan kreatinin yang tinggi tetapi pada penelitian ini tidak 
ditemukan adanya penderita gangguan ginjal. (Erdiansyah., 2010). Pada umumnya pria setiap hari minum kopi dan tidak memperhatikan mengkonsumsi makanan yang mengandung purin seperti durian, melinjo/emping, jengkol ,petai, tape , sarden, remis, kangkung. Makanan yang di konsumsi dapat meningkatkan kadar asam urat. Nilai normal kadar asam urat laki-laki 3,4-7,0 mg/dl

Ada faktor lain yang menyebabkan kenaikan kadar asam urat pada usia diatas 45 tahun keatas yaitu obesitas, tekanan darah tinggi,kadar kolesterol darah yang tidak normal dan pada laki-laki yang suka mengkonsumsi minum alkohol dengan tingkat berat dan makanan yang mengandung purin tinggi seperti jeroan, kepiting, kerang, keju, kacang tanah, bayam, buncis, mentega, durian, melinjo/emping, jengkol, petai, tape, sarden, santan, alpukat, gorengan.(Setyoningsih, 2009)

B. Kategori Pemeriksaan Kolesterol Pria peminum kopi

Tabel 2. Kategori Pemeriksaan Kolesterol Pria peminum kopi

\begin{tabular}{|c|c|c|c|}
\hline \multirow[b]{2}{*}{$\begin{array}{l}\text { Kategori } \\
\text { pemeriksaan }\end{array}$} & \multicolumn{2}{|c|}{ Kolesterol } & \multirow[b]{2}{*}{ Total } \\
\hline & Normal & Tinggi & \\
\hline Ringan & 20 & 29 & 49 \\
\hline Berat & 7 & 14 & 21 \\
\hline Total & 50 & 20 & 70 \\
\hline
\end{tabular}
pria peminum kopi sampel yang diguanakan sebanyak 70 orang. Peminum kopi pada kategori asam urat peminum kopi ringan kolesterol normal sebanyak 20 orang dan kadar asam urat tinggi sebanyak 29 orang sedangkan peminum kopi berat kadar asam urat normal sebanyak 7 orang dan kadar asam urat tinggi sebanyak 14 orang. Kadar kolesterol tinggi pada pria peminum kopi ringan sebanyak 29 orang sedangkan kolesterol tinggi pada pria peminum kopi berat sebanyak 7 orang, hal ini disebabkan karena adanya kandungan kafestol dan kahweol pada minyak biji kopi yang dapat meningkatkan adar kolesterol dalam darah.

Kahweol dan kafestol adalah alkohol diterpen pentasiklik yang merupakan senyawa yang memiliki kadar yang berbeda pada biji kopi akibat proses pemanggangan. Kedua senyawa ini memiliki efek positif bagi kesehatan manusia seperti antioksidan, anti-inflamasi dan hepatoprotektor (melawan kanker), serta memiliki efek negatif seperti faktor penyebab hypercolesterolemic. (Dias et al., 2013)

Kedua hal tersebut tentunya dapat meningkatkan resiko terjadinya penumpukan kolesterol dalam pembuluh darah yang dikenal dengan arterosklerosis. Hal tersebut mengakibatkan saluran 
pembuluh darah, khususnya pembuluh darah koroner menjadi sempit dan menghalangi aliran darah di dalamnya. Keadaan ini dapat meningkatkan resiko penyakit jantung koroner (PJK) dan stroke. Jumlah konsumsi kopi yang berlebihan ini menyebabkan kandungan kafestol yang masuk ke dalam tubuh juga akan lebih banyak. Hal tersebut menyebabkan fungsi kafestol dalam menghambat proses beta oksidasi akan terus berlangsung, sehingga kadar kolesterol total dapat meningkat (Diarti et al., 2016).

\section{KESIMPULAN}

Berdasarkan hasil penelitian dapat ditarik kesimpulan yaitu sebagai berikut

1. Pria peminum kopi ringan peningkatan asam urat sebanyak 11 orang sedangan peminum kopi ringan peningkatan asam urat sebanyak 9 orang

2. Pria peminum kopi ringan peningkatan kolesterol sebanyak 29 sedangkan peminum kopi ringan peningkatan asam urata sebanyak 14 orang.

\section{DAFTAR PUSTAKA}

Asaidi, M., 2010. Waspada Asam Urat. Diva Press : Yogyakarta.

Budiono. A., Aaltje. E. M., Widhi. B., 2016. Hubungan Kadar Asam Urat dengan Status Gizi pada Remaja di
Kecamatan Bolangitang Barat

Kabupaten Bolaang Mongondow

Utara. Jurnal e-Biomedik (eBm), 4:2.

Diarti, W. M., Iswari. P., Siti. R. S., 2016.

Kadar Kolesterol Total Pada

Peminum Kopi Tradisional Di

Dusun Sembung Daye Kecamatan

Narmada Kabupaten Lombok Barat.

Jurnal Kesehatan Prima. 10 : 16261637.

Dias R. C. E., Adelia F. De Faria., Adriana

Z. M., dan Neura B., 2013. Comparison of Extraction Methods for Kahweol and Cafestol Analysis in Roasted Coffee. Jurnal Braz. Chem. Soc. 24(3) : Hal 492-499.

Erdiansyah NP., 2010. Faktor-faktor Yang Berhubungan Dengan Kejadian Hiperurisemia Pada Pasien Rawat Jalan RSUP Dr. Kariadi Semarang. Program Studi S1 Ilmu Gizi Fakultas Kedokteran Universitas Diponegoro. 1: 10

Fujikawa, S., Iguchi, R., Noguchi, T., \& Sasaki, M. 2015. Cholesterol crystal embolization following urinary diversion: a case report]. Hinyokika Kiyo. Acta Urologica Japonica, 61(3), 99-102.

Guyton, AC., dan Hall, JE. 2007. Text Book of Medical Psysiology. Philadelphia: Elsevier Saunders. 
Kemenkes RI., 2004. Survei Kesehatan Rumah Tangga. Jakarta: Badan Litbangkes Kemenkes RI.

Kumalasari T, Saryono, Purnawan Iwan., 2009. Hubungan Indeks Massa Tubuh dengan Kadar Asam Urat Darah pada Penduduk Desa Banjaranyar Kecamatan Sokaraja Kabupaten Banyumas. Jurnal Soedirman, 4:3.

Ling Qiu, X.-q. C. 2013. Prevalence of hyperurecemia and its related risk factors in healthy adults from Northern and Northeastern hinese rovinces. BMC Public health, 13:664.

National Heart Lung and Blood Institute. 2011. High Blood Cholesterol. National Institutes of Health. Department of Health and Human Services. USA.

Pusriningsih, S. S. 2014. Hubungan Asupan Purin, Vitamin C dan Aktivitas fisik terhadap Kadar Asam Urat Pada Pemula Remaja Laki laki.

Setyoningsih R. 2009. Faktor-Faktor Yang Berhubungan Dengan Kejadian Hiperurisemia Pada Pasien Rawat Jalan RSUP Dr. Kariadi Semarang. Program Studi S1 Ilmu Gizi Fakultas Kedokteran Universitas Diponegoro: 9.
Sustrani, L., Syamsir, A dan Iwan. H., 2008. Asam Urat, Informasi Lengkap Untuk Penderita dan Keluarganya. Edisi 6. PT Gramedia Utama: Jakarta.

Wulandari, d. Y. (2016). Cara JItu Mengatasi Asam Urat. Yogyakarta: ANDI. 